\title{
Mid and Late Holocene flooding reconstruction based on fluvial archives of the East Carpathian rivers
}

\author{
Maria RĂDOANE ${ }^{1}$, Francisca CHIRILOAEI ${ }^{1}$, Nicolae RĂDOANE ${ }^{1}$, Constantin NECHITA ${ }^{2}$ \\ ${ }^{1}$ Department of Geography, Faculty of History and Geography, "Ștefan cel Mare" University of Suceava, \\ Suceava, Romania \\ 2"Marin Drăcea" National Institute for Research and Development in Forestry, Câmpulung Moldovenesc, \\ Romania
}

Received 30 June 2018; Revised 15 September 2018; Accepted 20 September 2018

*Correspondence to: Maria RĂDOANE, e-mail: radoane@usm.ro

\begin{abstract}
This paper focused on the analysis of the interpretation potential given by fluvial archives, in order to decipher the Mid- to Late Holocene sedimentary history. The database discussed here refers to 65 dated ages (mostly radiocarbon), mappings of the most representative floodplain reaches of Suceava, Moldova and Siret rivers, and 23 outcrops analysed in floodplain deposits (river banks or gravel pits). The study results concentrated on (a) describing the regional features of Eastern Carpathian floodplains, (b) the floodplain morphology and its correlation with the structure of fluvial deposits and (c) identifying the paleoevents of fluvial activity on a centennial timescale. In this way, we were able to identify a general pattern of the dynamic geomorphology history for the rivers situated eastward of the Carpathians, which resulted from combining the Mid- to Late Holocene sedimentation phases, the avulsion and lateral migration processes that occurred during high fluvial activity intervals and the morphological adjustment of the rivers channels, from braiding to wandering and sinuously-meandering. The chronological overlay of the events revealed that the time intervals with the most extensive fluvial processes on the rivers draining the Eastern Carpathians occurred (in years before present) during 6200, 5300, 4100-4080, 3600, 2300-2200 (Iron Age), 1300 (Migrations Period), 950-970 (Medieval Climate Anomaly), 750-520 BP (Little Ice Age) and that these intervals generally overlap the high precipitation palaeoclimatic episodes documented in Romania. The fluvial activity of the rivers during the Mid- to Late Holocene has been compared as well with several records of paleo-climates variability over the geographical area of Romania. The result showed that many flooding episodes were coincident with the wet and cold intervals which were also identified in the variation of the other proxy data, especially after $4.7 \mathrm{kcal}$ BP.
\end{abstract}

KEYWORDS

fluvial sediments; age dating; channel sedimentation and incision; flooding events chronology 


\section{Introduction}

The paleohydrology and fluvial paleogeomorphology studies in Romania are relatively scarce. It was only after 2010 that a real recovery manifested in this way, the Holocene paleoevolution getting the attention of geomorphologists within a broader spectrum of landform types, not only with respect to the fluvial one. Various analyses starting from the integrated reconstruction of the Holocene evolution of the Danube Delta based on new evidences (Vespremeanu-Stroe et al., 2017), to the estimation of landslides activity during the Holocene on the sites with archaeological inheritance from the Moldavian Plateau (Niculiță et al., 2016) or to the evolution of sedimentation in small lake bodies (Mîndrescu et al., 2017) represent the range of references that confirm the statement above. The paleoclimatology studies complete these researches by contributing to understanding the role of climate in Holocene landforms dynamics. The synthesis of Perșoiu and Rădoane (2017) reviews the most notable studies regarding the knowledge of river channels patterns and change degree at different time levels (centennial and millennial, Late Holocene, Holocene, Late Glacial and the transition to Holocene). The most important conclusion of this synthesis reveals the high sensitivity degree of the rivers response to changing control factors, whether it is climate change, base level modification or human impact. The archive that preserves the "witness of change" status (according to Cordier et al., 2017) is built of alluvial assemblages created by authigenic sedimentation processes in a floodplain sector (Lewin et al., 2005). Despite their numerous limitations (listed by Lewin and Macklin, 2003), fluvial archives are considered valuable paleoenvironmental records, as proved by the publications of the FLAG work group (Fluvial Archives Group, 1996), a component group of the Water Framework Directive (WFD, 2000) of the European Union.

In this study, we aim to highlight the progresses in the interpretation of alluvial facies in correlation to floodplains morphology to ultimately discern the hydro-geomorphological paleoevents. This is an idea that started from the study of present river channels dynamics and of the human intervention influence in the last 50 years (Rădoane et al., 2013), continued with comprehending the mechanisms that adjusted the fluvial patterns for the last 150 years (Rădoane et al., 2017) and further on, for the Mid to Late Holocene (Chiriloaei et al., 2012; Rădoane et al., 2015) and Holocene (Rădoane et al., 2018). Here, we intend to harness our experience and database concerning the fluvial sediments archives from rivers floodplains and to illustrate this on a number of study cases of rivers from the eastern area of Romania. Amongst the discussed problems, we will particularly refer to: a) regional characteristics of the East-Carpathian floodplains; b) floodplains morphology and its correlation with floodplain deposits structure; c) deciphering the paleoevents of fluvial activity by using absolute dating of the fluvial sedimentary units.

\section{Geographical setting}

Our researches are located on multiple reaches of three important rivers that drain the eastern side of the Eastern Carpathians: Siret river and its right tributaries, Suceava and Moldova rivers (Table 1, Fig. 1).

The geologic substrate of Siret river basin is formed by a succession of strips oriented NW-SE that unfolds from west to east as follows: the volcanic area (1.33\% of the basin area), the crystallineMesozoic area (6.79\% of the basin area), the Flysch area $(33.29 \%)$, the Neogene molasse area (10.12\%) and the area of the platform-like sedimentary rocks (47.94\%). The relief shaped on this substrate develops in steps from west to east and it is fragmented by a hydrographical network with an asymmetric layout towards the main river, Siret. The development of a well-individualized piedmont at the eastern border of the Carpathians and Subcarpathians is a relevant indicator of the long-term existence of coarse alluvial sediments consistent transport. This specific area is well-known to the Romanian geomorphologists as the Moldavian Piedmont, which started to form in the Sarmatian (on Fig. 2, this area is highlighted by the greater thickness of the Quaternary deposits from valley bottoms). Presently, this piedmont-like area is partly eroded, especially in its northern sector. 
Table 1 Data on the studied river reaches

\begin{tabular}{|c|c|c|c|c|c|c|c|}
\hline River & $\begin{array}{c}\text { Drainage } \\
\text { basin area } \\
\text { upstream } \\
\text { of the } \\
\text { study area, } \\
\text { A }\left(\mathbf{k m}^{2}\right)\end{array}$ & $\begin{array}{l}\text { Reach } \\
\text { length, } \\
\text { L, (km) }\end{array}$ & $\begin{array}{l}\text { Average } \\
\text { channel } \\
\text { slope, S, } \\
(\mathrm{m} / \mathrm{km})\end{array}$ & $\begin{array}{c}\text { Discharge, } \\
\text { mean } \\
\text { annual, } \\
Q^{*}, \\
\left(\mathrm{~m}^{3} / \mathrm{s}\right)\end{array}$ & $\begin{array}{l}\text { Discharge, } \\
\text { annual } \\
\text { maximum, } \\
\text { Qmax*, } \\
\left(\mathrm{m}^{3} / \mathrm{s}\right)\end{array}$ & $\begin{array}{c}\text { Suspended } \\
\text { load, } \\
\text { mean } \\
\text { annual, Qs*, } \\
(\mathrm{kg} / \mathrm{s})\end{array}$ & $\begin{array}{c}\text { Bed } \\
\text { material } \\
\text { median } \\
\text { diameter, } \\
\text { D50, } \\
(\mathrm{mm})^{* *}\end{array}$ \\
\hline $\begin{array}{l}\text { Siret (between } \\
\text { Suceava cf. to } \\
\text { Moldova cf.) }\end{array}$ & 5,921 & 144 & 0.41 & $36.80^{a}$ & $503^{a}$ & $52.9^{a}$ & 11.2 \\
\hline $\begin{array}{c}\text { Suceava } \\
\text { (between } \\
\text { Milișăuți to Siret } \\
\text { cf.) }\end{array}$ & 2,334 & 128 & 2.00 & $16.49^{b}$ & $381^{b}$ & $21.9^{b}$ & 20.0 \\
\hline $\begin{array}{c}\text { Moldova } \\
\text { (between Molid } \\
\text { to Siret cf.) }\end{array}$ & 4,316 & 110 & 0.82 & $32.80^{c}$ & $546^{c}$ & $35.3^{c}$ & 17.0 \\
\hline
\end{tabular}

*measurement period: 1967-2010; a - Lespezi gauge station; b - Ițcani gauge station; c - Roman gauge station; ** cf Rădoane et al., (2008)

The piedmont-like activity is still present and it is visible in the behaviour of the river channels when leaving the mountain area (for example the braiding and even the avulsion and longitudinal profile deformation of Siret river - Ichim and Rădoane, 1990; Rădoane et al., 2008). On the investigated sectors, the rivers are semi-constrained (with a constraint degree of $35-40 \%$ ), more significant on Siret river because of the contact with the Moldavian Plateau and with the front of the high terraces. Differences occur between the current typology of Siret river channel (sinuously meandering) and the one of the two tributaries (braided channel with tendency towards wandering near the confluence with Siret, more sharp in the case of Suceava river). Instead, a relative balance is noticed between the studied river reaches in terms of dimension, the type of material in the channel, the amount of water and sediment discharges (Table 1).

\section{Data and Methods}

The data providing the basis of the results presented here were obtained from our own researches comprising extensive field activities at 23 sites distributed along Siret (6 sites), Suceava (7 sites) and Moldova river (10 sites) which consisted of anthropic outcrops (sand and gravel pits) and natural exposures (river banks) in floodplain deposits. Radi- ocarbon and OSL dates were published (Chiriloaei et al., 2012; Rădoane et al., 2015) or are currently in press in the framework of country-scale syntheses (Rădoane et al., submitted).

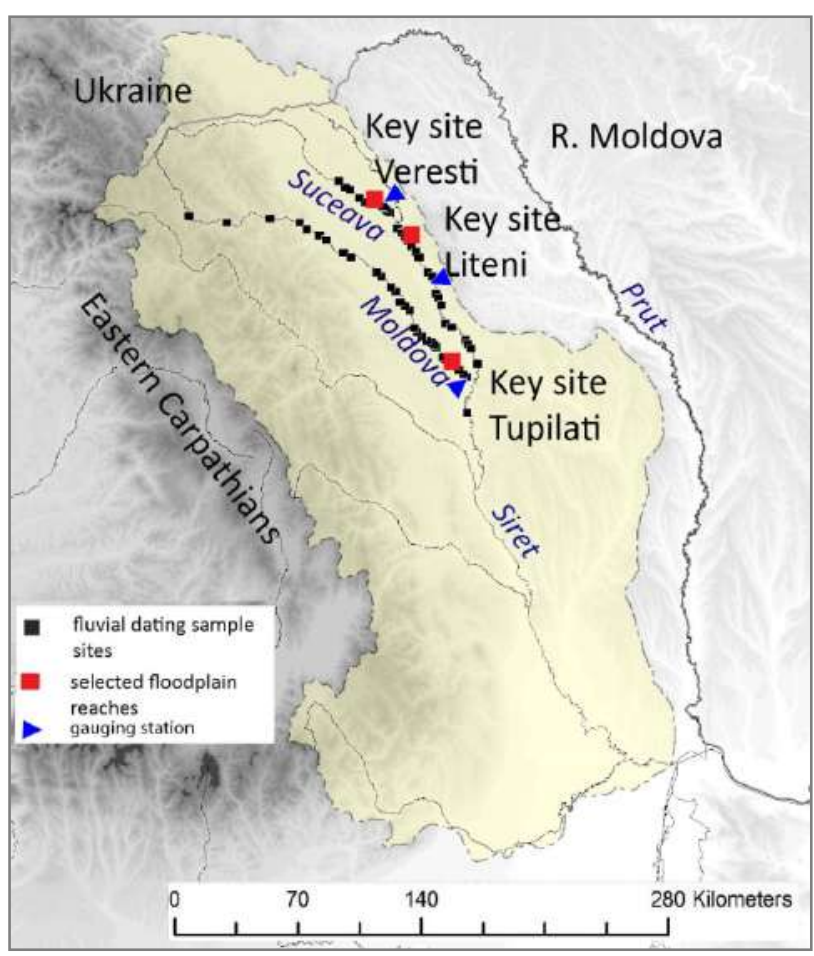

Figure 1 Location of sites along the studied rivers, with $14 \mathrm{C}$ dated river flood sediments. For each river a key floodplain reach was selected 
The absolute ages database is made of 65 age dates of the fluvial sedimentary structures (60 radiocarbon, 2 OSL (Optically Stimulated Luminescence) and 3 dendrochronological datings; the latter dating method was applied to sub-fossil oak trunks trapped in the floodplain sedimentary structures).

For each dating, the following additional details were recorded: geographical setting (relief unit, drainage basin, river name, and geographical coordinates), altitude, distance from the source of the river at each site, the drainage basin area upstream the site location, information regarding the collected material, the stratigraphic position and the depth of the dated formation reported to the floodplain level. The spatial distribution of these data is presented in Fig. 1. Based on the experience accumulated in cautiously selecting age dating (Macklin and Lewin, 2003; Johnstone et al., 2006; Benito et al., 2015; Rossato et al., 2015; Faust and Wolf, 2017), in each distinct case we recorded the sedimentation context from which the sample had been selected. Every outcrop has been mapped and drawn to scale in order to identify and describe the sedimentary facies and the architectural elements such as in Miall (1985). The database obtained in this way was integrated in the general context of East-Carpathian rivers floodplains formation, the general characteristics of each being discussed below.

Therefore, the 14C, OSL and dendrochronological age datings are distributed on an altitudinal range between 200 and $550 \mathrm{~m}$. These are the altitudes that comprise the floodplains extent of the three investigated rivers where we encountered frequent outcrops and datable samples. The greatest number of age datings ranges in the altitudinal class between 250-300 m (Fig. 2A). The drainage basin areas controlling the dated floodplain sections extend between $2000-7000 \mathrm{~km}^{2}$ (in the case of Suceava and Moldova rivers) and between 9000$12,000 \mathrm{~km}^{2}$ for Siret river. The jump in the size of drainage basins is visible in Fig. $2 \mathrm{~B}$ and it is given by the fact that Suceava and Moldova are VII ${ }^{\text {th }}$ order rivers (in Strahler system) compared to Siret, which is a VIII ${ }^{\text {th }}$ order river.

The calibrated ages of the fluvial sedimentary units indicate a plethora covering the last 10,000 years (Fig. 2C), with a higher density in the last 7000 years. Their distribution with the sampling depth presents a wide variation of the fluvial units' age on the same depth, but also a slight age increasing tendency when sample location are getting deeper. In other words, as the sedimentary unit is located deeper, it gets older. On the other hand, the correlation is quite low-sensitive, due to the fact that fluvial sedimentation in floodplains undergoes intense and frequent reworking, therefore datable samples from older sediments could be eroded and re-deposited in a stratigraphic position closer to the surface. Nevertheless, the general tendency of the oldest sedimentary structures being found at the highest depths in the floodplain deposits is noteworthy.

The investigated fluvial sedimentary units are indicated in Fig. 2D, where they were classified as proposed by Miall (1985) and Lewin et al. (2005). The highest share of the identified and dated sedimentary structures belongs to channel bed gravel deposits opened in the channel banks and mostly in gravel quarries. In such deposits we identified the trunks of the subfossil trees that we dated (cf. Figs. $4,5,6)$. Some other categories of fluvial units were the gravel lobes with finer grain-size due to lateral accretion, the fine gravel and sand bars, paleochannels fillings and flood deposits, all of which were identified in the openings from the lower floodplain adjacent to the river channel, or in the floodplain terraces.

In the following, we will insist on several defining characteristics of the East-Carpathians rivers based on the hundreds of drillings performed, in order to better comprehend the specificity of the Holocene and recent fluvial activity of these rivers.

\section{Some characteristics of the East-Car- pathian rivers floodplains}

The general features of the East-Carpathian river valleys, especially those located north of Trotus fault, reflect their evolution on nearly the same courses ever since the Sarmatian ( 13.5 million years ago) (Donisă, 1968; Rădoane et al., 2003). The energy-environment of rivers maintained high for a long time, leading to the transport of large amounts of coarse sedimentary materials for a longer period of time. This transport and sedimentation pattern is 
reflected by the structure of the East-Carpathian rivers fluvial terraces and especially by their floodplains. The alluvial history of Siret river represents a distinct situation. Although this river flows mostly over a plateau, it has all the features of a Carpathian river, because of the granulometric and petrographic natures of the deposits from the river bed. The large amount of coarse sediments brought by the right bank tributaries from the Carpathians, caused much aggradation of the river bed and consequently, distorted the longitudinal profiles (Rădoane et al., 2008).

The floodplains of the East-Carpathian rivers are characterized by a morphology and structure of the sediments deposit that reflects the Late Quaternary fluvial evolution common to all the rivers from Central and Eastern Europe (cf. Starkel et al., 2015; Perșoiu et al., 2017). The oldest formations identified and dated so far covered mainly the Middle Pleniglacial - Late Glacial period (MIS 3, MIS 2; ca. $59,000-11,700$ yrs BP). The rivers that drain the SE Carpathians provide an exceptional situation, as the positive tectonic movements have determined a 250 $\mathrm{m}$ incision of the river network. The age of the fluvial formations that accompany these valleys was documented so far as the Eemian - Early Pleniglacial (MIS 5, MIS4) (Necea et al., 2013).
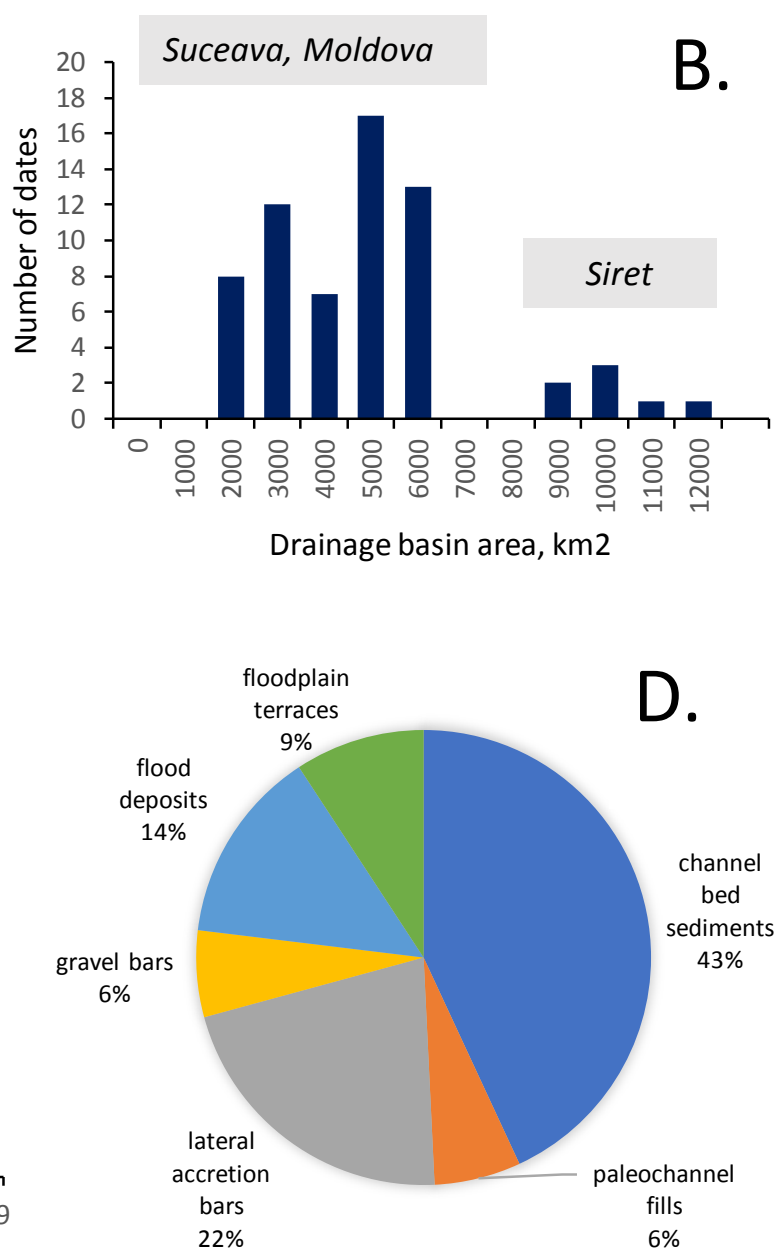

Figure 2 The distribution of age datings of the studied fluvial archives: (A) number of age datings of the investigated sites on altitude classes; (B) frequency of datings on size classes of the drainage basins situated upstream of the study sites; (C) the age of the fluvial units in relation to sampling depth; (D) the distribution of age datings by type of fluvial deposits 
The several hundred boreholes performed in the floodplains of Siret river and of its tributaries coming from the Carpathians (Suceava, Moldova) (Fig. 3. A, B) have shown that the longitudinal profile of the fossil river-bed is not regular, presenting an alternation of deepening sectors (up to $18-20 \mathrm{~m}$ in this case), separated by sectors in which the fossil bed is found at a lower depth (4-8 m). On Suceava river, the greatest thickness of the floodplain deposits occurs at the contact between orogeny and platform, overlaying the Rădăuți depression where there is a considerable widening of the valley bottom (Fig. 3A).
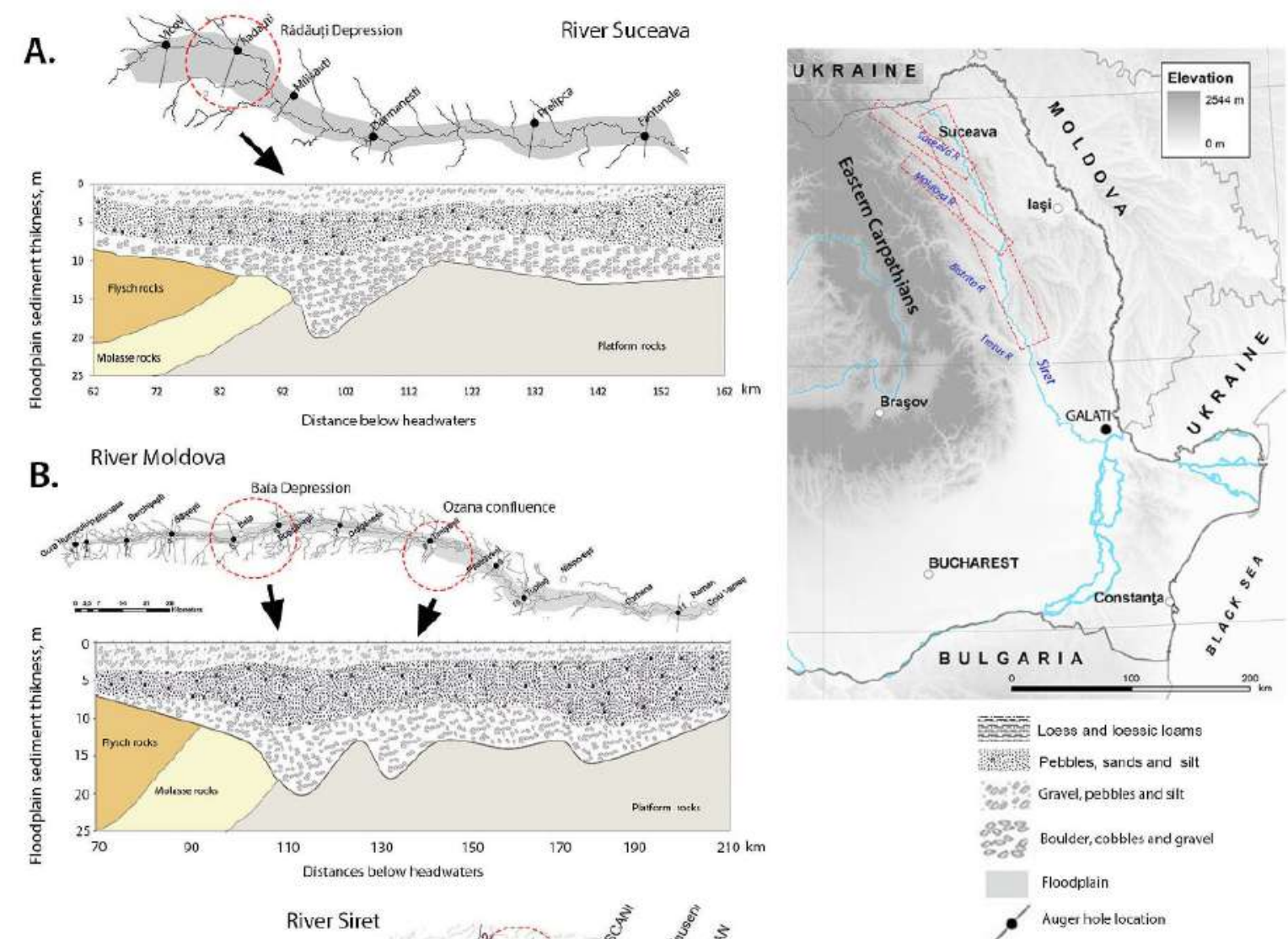

C.
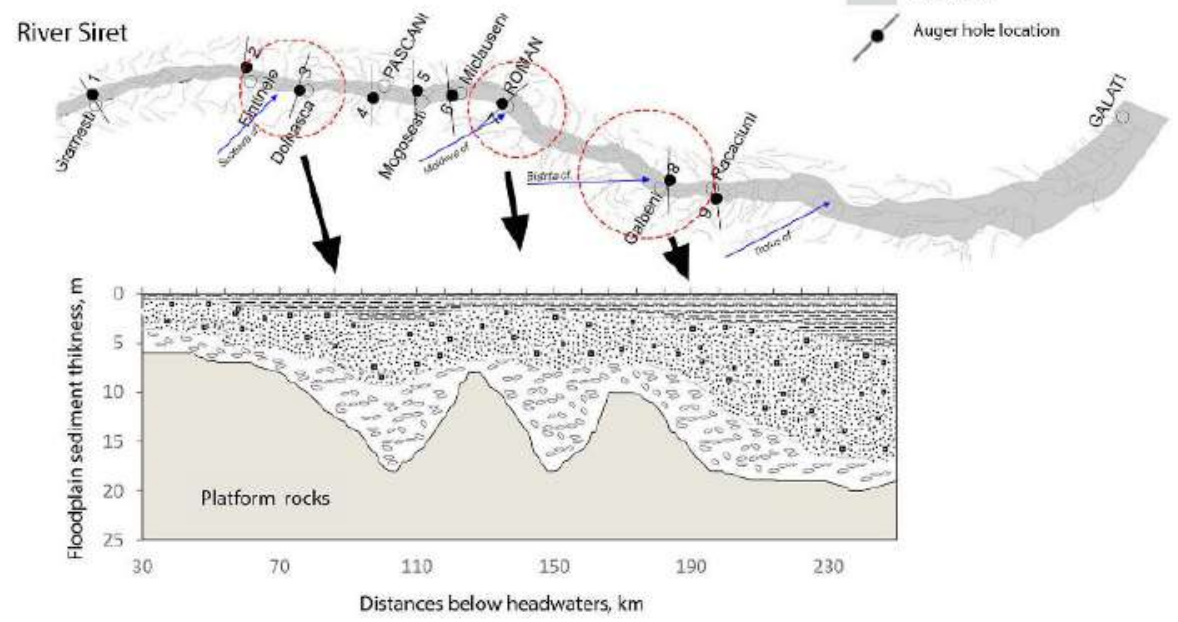

Figure 3 Suballuvial morphology and sedimentary fill of some Carpathian rivers: A. River Suceava, middle reach; B. River Moldova, out - Carpathian reach; C. River Siret, out - Carpathian reach; D. Exemplified rivers and their location in the geographical area of Romania. Discussions in the text 
A similar phenomenon can be noticed on Moldova river, at the exit from the mountainous area of the river (Baia depression marking the area at the surface), where the thickness of the alluvial sediments reaches maximum depths. Additionally, the depth of the alluvial sediments increases along the valley at the confluences with prolific tributaries such as Ozana or Topolița. In the case of Siret floodplain, the suballuvial morphology is strongly controlled by its forceful Carpathian tributaries, so that at the confluences with Suceava, Moldova, Bistrița and Trotuș the bed of the floodplain decreases with 15 to 20 m (Fig. 3C).

Regarding the structure of the floodplain alluvial deposits, the boreholes allowed us to synthesize the stratigraphic arrangement of the valleys filling deposits, as follows:

i) a thick complex, formed by gravel and boulders, generally situated in the alluvial bed of the valley on all the three exemplified rivers. Its thickness varied from 4-5 $\mathrm{m}$ in the deepening sectors of the fossil bed and up to less than $2 \mathrm{~m}$ in the shallower sectors. The age of these gravels was determined at the base of an opening over $9 \mathrm{~m}$ depth at Liteni (on Siret r.) and was estimated at 20.3 YBP (Rădoane et al., 2015), which is typical for the Late Glacial - Holocene transition;

ii) another sedimentary pile formed next, consisting in finer gravel with a sandy matrix 2 to $5 \mathrm{~m}$ thick, which presented an increasing tendency along the rivers. In the upper part of the floodplains we identified a differentiation between Suceava and Moldova rivers on one side and Siret river on the other side. In the floodplain of Siret river, the upper reach is dominated by fine materials, stratified sands and thick deposits of loams, especially on the 5-7 m high floodplain terraces. Instead, on Suceava and Moldova tributaries, the upper part of the boreholes reveal a consistent pile of uneven-sized gravels that extended up to $4 \mathrm{~m}$, and which, as described in the following sections of the paper, are linked to the fluvial activity during certain phases of Mid an Late Holocene periods.

Summing up, the shape of the sub-alluvial valleys as well as the thickness and disposition of the sediments along the longitudinal profile of rivers floodplains reflect, at least for the exemplified rivers, the closeness of the Carpathian source area and the intensity of the tectonic movements. These two main causes are in charge of the irregular morphology of valleys incision (depths alternance of over 20 $\mathrm{m}$ with sectors where the fossil bed is close to the surface) and of the thickness of floodplain sediments deposits. Particular to sediments accumulation in the floodplains of the East-Carpathian rivers is the successive alluvial fans formation mechanism along the rivers, which maintains active in the present. The age of the incision formed in the fossil bed of the valleys has been determined as MIS3, MIS2 (for the VII ${ }^{\text {th }}$ order rivers in Strahler system) and MIS4 (for II ${ }^{\text {nd }}$ and III ${ }^{\text {rd }}$ order valleys in Strahler system) (cf Perșoiu et al., 2017).

\section{Floodplains geomorphology and corre- lation with their stratigraphical structure}

In order to obtain a more comprehensive Holocene fluvial history of the investigated hydrographic systems, in this section, based on the stratigraphical information from the field, we made a synthesis of certain sedimentation patterns that are representative for the studied geographical area. The surface morphology of the river floodplains alluvial complexes was coupled to the investigations on the natural and artificial openings in floodplain deposits. In each of the three key sites that we described we benefited of more outcrops in the floodplain deposits based that we used to accomplish the composite stratigraphic sequences. An individual and analytical presentation of each site is given below.

\subsection{Verești site, Suceava river}

This key site is located at about $15 \mathrm{~km}$ upstream of the confluence with the collecting river Siret, and it was chosen for its representative profile of the floodplain deposits built along the $35 \mathrm{~km}$ of the channel that were investigated. The floodplain is 2.5 $\mathrm{km}$ wide and it is bordered by the 10-15 m terrace (on the left side) and by the hillslope of Suceava Plateau (on the right side). The general morphology of the floodplain was mapped in detail and the results are presented on the geomorphological map of the $10 \mathrm{~km}$ long reach (Fig. 4A). The channel of Suceava river is sinuous-wandering with alternating 
bars made of gravels with a mean grain size of 15$20 \mathrm{~mm}$. The active belt where the channel migrates without constrains during the maximum annual discharges (cf Bridge and Leader, 1979) represents the lowest level within the floodplain (below 1.5-2 m). Its width in this sector is around $200-300 \mathrm{~m}$. There are several generations of abandoned channels distinguishable over the floodplain surface, which are deepened in three floodplain levels: $2.5-3$ $\mathrm{m}, 3.5-4 \mathrm{~m}$ and 5-7 m (Fig. 4A).

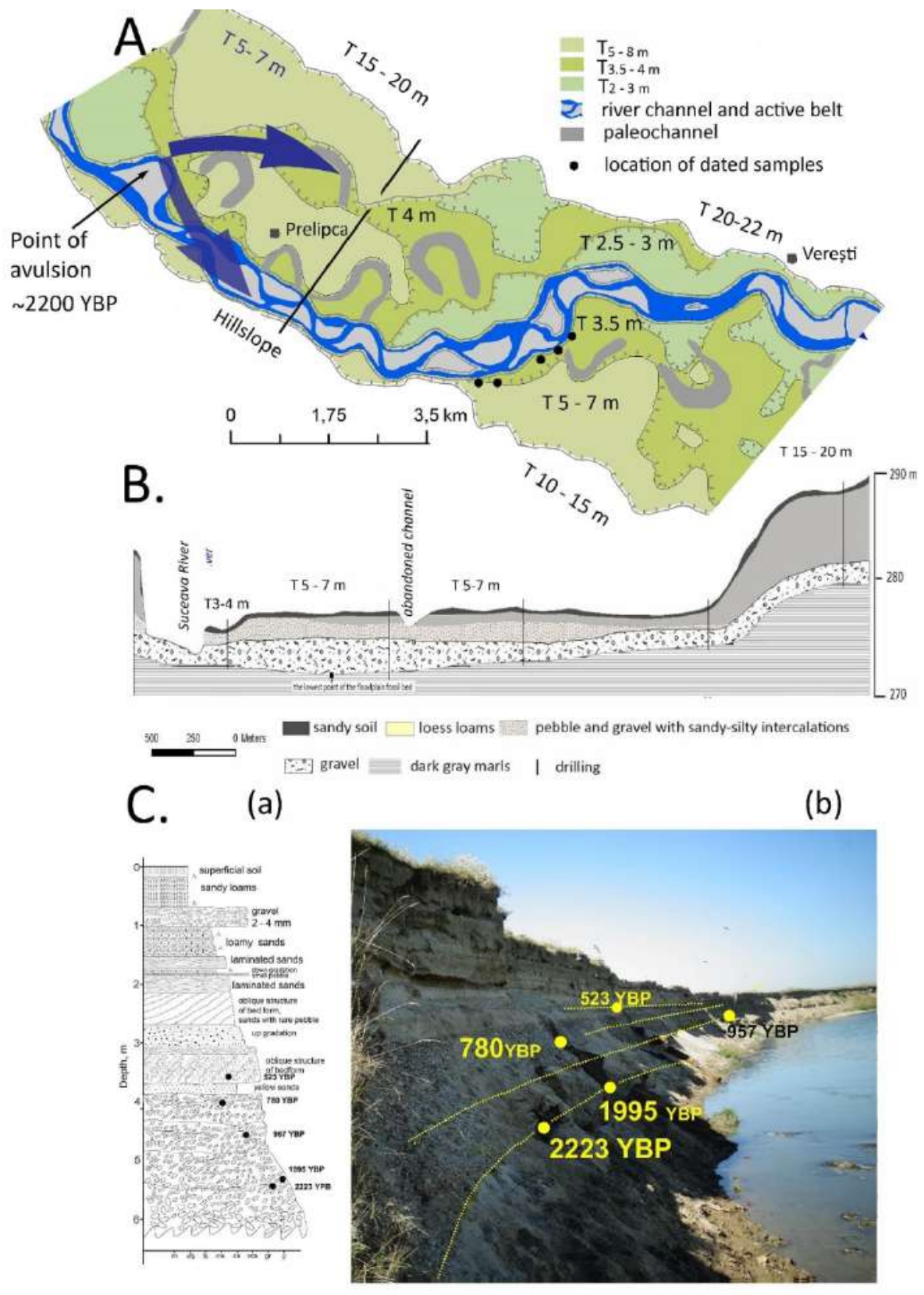

Figure 4 A. Geomorphological map of Verești site reach (to see Fig.1 to locate); B. Cross-section through floodplain fill (modified after D. Oprea, 2014); C. Lithostratigraphical profile (a) and radial gravel lobes in the right concave bank of the river and their ages in YBP (b). See discussions in the text

A series of 5 boreholes performed by SGA (Sistemul de Gospodărire a Apelor, in ro) Suceava (cf Oprea, 2014) on a transverse profile in this sector
(Fig. 4B) allowed us to get a closer look on the sedimentary structure of the deposits. The fossil bed of the floodplain is situated at a maximum depth of 
ca. $2 \mathrm{~m}$ lower than the present river bed and it is positioned around $1.5 \mathrm{~km}$ left of the present course. This fossil bed is formed in the Lower Sarmatian sedimentary complex and it is built mainly of compact purple marls. The coarse gravels that form the basis of the floodplain alluvial deposit are maximum $3 \mathrm{~m}$ thick. Over this gravels level there is a 1 to 2.5 $\mathrm{m}$ thick horizon of small pebbles with sandy matrix and at the surface there are sands and loessoid loams that lay on the 5-7 m floodplain level. This area was the highest from the mapped floodplain sector, therefore it had the conditions to develop and presently maintain in the Prelipca village territory. Westward of this floodplain level there are surface traces of a former course of the channel, on which we will return.

The loops of the river channel sinuosities contain openings in the floodplain deposits that reveal its structure on 5-7 m thickness, down to the bedrock. The profile presented in Fig. $4 \mathrm{C}$ revealed a sediment pile comprised between 3 and $6.5 \mathrm{~m}$, finally reaching the bedrock. This makes us believe that the present course of the channel is deviated laterally of the older one. Due to the relatively recent incision of the channel ( $-1.5 \mathrm{~m}$ since 1963 until the present, cf. Rădoane et al., 2013) and to the lateral erosion in the concave banks, the structure of the floodplain deposits was visible and we were able to describe it. The main sedimentary units are visible in the lithostratigraphic profile analysed on the right concave bank of the river (Fig. 4C): a 2.5 m thick unit formed by coarser gravels ( $D 50=15-20 \mathrm{~mm}$ ) at the base (the contact with bedrock) which are getting smaller (D50 $=5-7 \mathrm{~mm}$ ) towards the upper part; a transition unit $1.2 \mathrm{~m}$ thick formed by small gravels (D50 smaller than $5 \mathrm{~mm}$ ) with oblique and laminary structures trapped in coarse sands horizons; a unit of finer sediments, sandy and clayey, with small insertions of small pebbles. Age datings for the sediment deposits from this profile prove that the alluvial processes on a new channel course started 2200 years BP ago. It was then when the river moved its course from the left side of the floodplain (highlighted on the map at west of Prelipca) towards the right slope through an ample avulsion phenomenon. In the following 1500 years, sedimentation continued on the present course of the channel; gravel horizons deposed interruptedly which buried no less than 15 oak truncks inventoried on this approximately $800 \mathrm{~m}$ long reach (Fig. 4A, C). The disposal and age of the truncks demonstrate that the alluvial processes occurred as flood waves that left behind radially disposed gravel lobes (Fig. 4C). After $523 \mathrm{YBP}$, the sedimentation manner continued, the lobes of small gravels and coarse sands with oblique structure being sedimented on the right bank of the river.

\subsection{The Tupilați site, Moldova river}

This site is represented by a $10 \mathrm{~km}$ long floodplain sector, where the surface morphology develops as follows: the fluvial migration corridor of the channel is over $1 \mathrm{~km}$ wide, comprising multiple islands and secondary branches of the channels. In the last 100 years the width of this active belt of the floodplain showed a gradual reduction (with up to $49 \%$, Chiriloaei, 2012) as the river channel modifies its typology from braided to wandering. The active belt is bordered by three levels, of $2.5-3 \mathrm{~m}, 4-5 \mathrm{~m}$ and 5.5 -6 m (Fig. 5A).

The age estimation for the accumulation that forms the floodplain of Moldova river was possible by combining the numerous radiocarbon datings made on the profiles opened in the gravel pits from this sector. The oldest gravel beds that have a direct contact with the base rock (Sarmatian marls) are 10 ka cal BP old (Fig. 5B) and represent the 4.5-5 m floodplain level that maintains on the left bank, at the contact with T 10-12 m. Within this accumulation an incision of the river occurred, separating the 3.4-4 $\mathrm{m}$ level. The lateral migration of the river between $10 \mathrm{ka}$ and 3-3.7 ka cal BP contributed both to the incision of the river and to the redistribution of the sedimentary material from the higher terrace. One of the high amplitude phenomena registered on Moldova river was the generalized alluvial sedimentation along the valley (at least upstream of Gura Humorului) with coarse materials that were deposited as a gravel sheet with an estimated thickness of 3-4 $\mathrm{m}$, which is well individualized also on the resistivity profile (Fig. $5 \mathrm{C}$ ) in the $3.5-4 \mathrm{~m}$ floodplain level. The age determinations based on the oak trunks embedded in this sediments deposit have revealed that the process occurred after epi- 
sodes of large floods (Chiriloaei et al., 2012; Rădoane et al., 2015). Besides, the composite lithostratigraphic profile (Fig. 5B) registers this layout of the gravel sheets with a rather chaotic structure, with small insertions of fine materials. On the top of the 3.5-4 m terrace, we identified several abandoned branches of Moldova river filled with fine sediments deposed in thin layers, their position revealing the high capacity of lateral migration of the river channel. Small floodplain levels of 1.5-2 m were subsequently shaped in the alluvial deposit of the 3-4 $\mathrm{m}$ terrace and are now connected to the present fluvial corridor. We estimated their age at 1.2-2.2 ka cal BP.
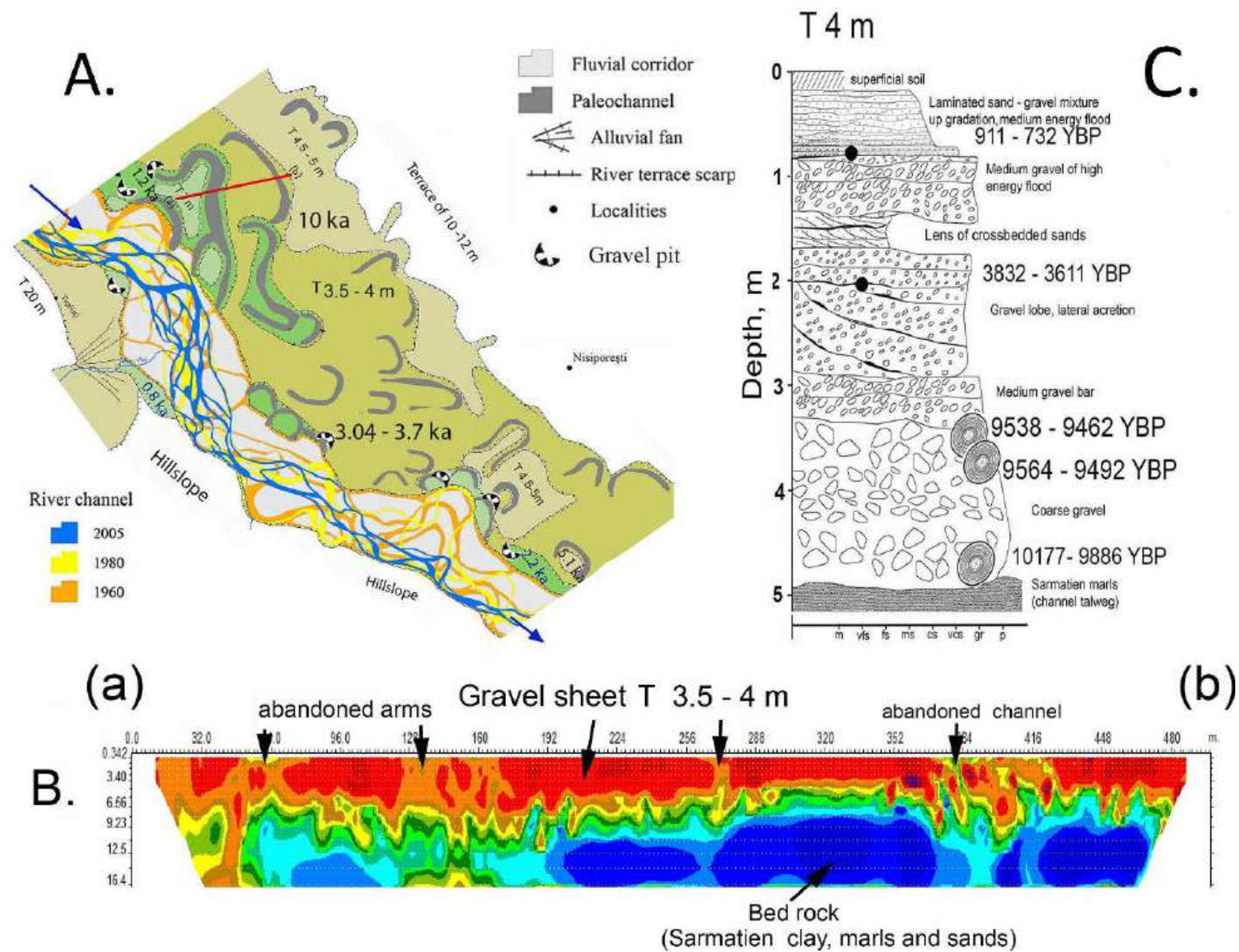

Figure 5 The key site Tupilați, on Moldova river (modified after Rădoane et al., submitted). A. The geomorphological map of the present dynamics of the river channel, the extension of the floodplain terraces and the estimation of their age based on the datings of the sediments deposits from the profiles uncovered in the gravel pits. B. Resistivity profile in floodplain deposits and old courses of the river channel. C. Lithostratigraphic profile respresentative for this sector

\subsection{Liteni site, Siret river}

Liteni site is situated just downstream of the confluence of Suceava and Siret rivers (Fig. 6). The site is exemplified by a composite profile which was described based on a $4 \mathrm{~km}$ long and 3-7 m thick opening in the floodplain sediments of this river (Fig. 6A) and on a geomorphological map of the floodplain covering ca. $8 \mathrm{~km}$ of the valley length
(Fig. 6B). The investigated river sector is characterized by a meandering to sinuous channel, with gravel bed and banks with mixed structure, with lateral accumulation sectors and well developed alternating bars. The surface morphology of the floodplain in this sector is composed of the active belt of a 700-800 m length and three levels of terraces $(2-2.5 \mathrm{~m}, 3-4 \mathrm{~m}$ and $5-7 \mathrm{~m})$ with nonuniform distribution. The relief from the top of the terraces 
preserves the traces of some old channel loops, presently silted.

The sedimentation history of the river begins with a layer of coarse, slightly cemented gravels which were dated at $20.3 \mathrm{ka}$ cal BP. The level of the gravels ends with an erosion line at a depth of 7.5 $\mathrm{m}$. The contact with the upper finer sediments is marked by a bed of oak logs, the oldest ones reaching $9.5 \mathrm{ka}$ cal BP. The upper sediment deposit is finer and finer towards the surface, and the ages succeed from $6.7 \mathrm{ka}$ cal BP to $2 \mathrm{ka}$ cal BP on the way to the upper part of the profile. The sedimentary unit situated 6-7.5 m deep is formed of lobes with a cross-bedded structure of fine gravel with coarse sands matrix. Their age ranges from $5.2 \mathrm{ka}$ cal BP to $4.9 \mathrm{ka}$ cal BP. These gravels are followed by meansize yellow sands horizons with rare grains of gravel, the age of which was estimated at about $3.65 \mathrm{ka}$ cal
BP at the upper part of the deposit. The succession of the horizons was interrupted by the incision of a channel, the contour of which $(64 \mathrm{~m}$ width and reaching a depth of $6 \mathrm{~m}$ ) could be determined clearly in the lithostratigraphic profile of the 5-7 m level terrace. The paleochannel was filled with fine sediments with laminary structure, rich in organic materials. The age of these sediments in the base of the paleochannel was dated at 2-2.2 ka cal BP. Therefore, we can assume that the paleochannels identified on the surface of the 5-7 $\mathrm{m}$ terrace were functional before $2.2 \mathrm{ka}$ cal BP. Afterwards, the channel migrated to the opposite bank, separating the succession of levels with lower altitudes. In the same terrace, but in a different site, we identified a fossil soil profile at $2 \mathrm{~m}$ depth below the sandy loams from the surface, which indicates that the terrace was not flooded after $2.2 \mathrm{ka}$ cal BP.
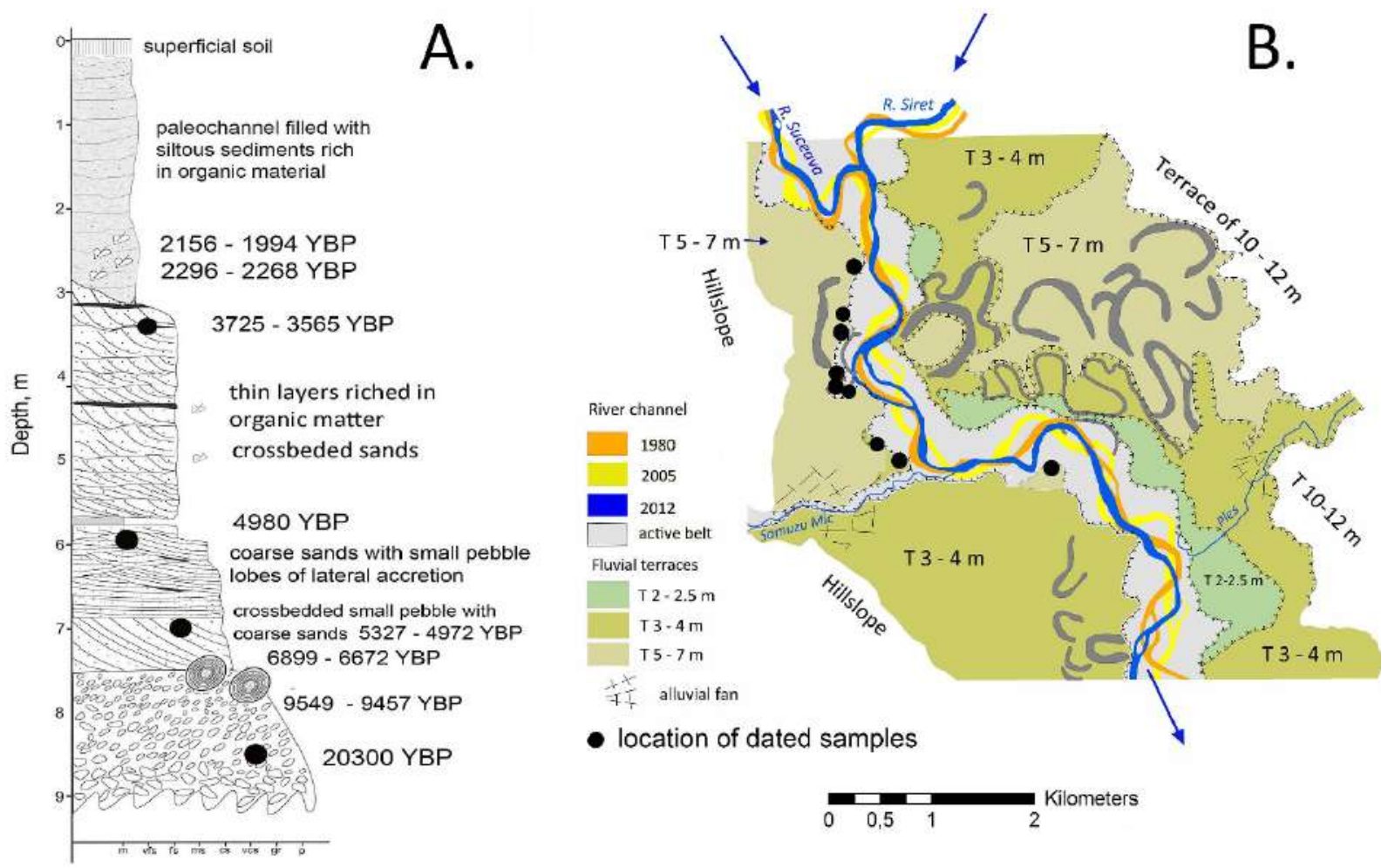

Figure 6 Liteni site: (A) Composite lithostratigraphic profile in the 5-7 m terrace of Siret river; (B) Geomorphologic map of the site and the location of the dated samples. Discussions in the text

\section{Discussions and conclusions}

The history of sedimentation in the floodplains that we exemplified here starts with coarse gravels deposition which, based on their age (older than $20 \mathrm{ka}$ cal BP in the case of Siret river) were put in place during the Late Glacial. This level of gravels and boulders proves the presence of high-energy braided water courses, a feature that has been proved and sustained for the evolutionary models of the rivers in our geographical area (Howard et al., 
2004; Perșoiu et al., 2017). On other exemplified rivers (e.g. Moldova), the age of the gravel located at the base of the profiles, where it reaches the bedrock, has been dated at 10.1-9.9 ka and presents a depositional model composed by sediment horizons with maximum grain size of 10 up to $15 \mathrm{~cm}$ which decreases gradually towards the upper part (diameters of $1-5 \mathrm{~cm}$ ). In the inventoried openings we only found the upper part of this level, the present level of the rivers oftenly reaching the bedrock (especially in Moldova and Suceava, process accentuated by the intense exploitation of the bed material).

The contact between coarse gravels (LG) and the transitional gravels ( $\mathrm{LG}-\mathrm{H}$ ) as well as other phases of fluvial activity during the Holocene was marked, at almost all the sections that we studied, by a quasi-continuous series of subfossil trunks. The position of these subfossil trunks and the coarse texture of the sedimentary material in which they are embedded, indicate the peak of a major flooding, the covering of the trunks occurring during the decreasing phase of the flood wave.

The sediments belonging to the Holocene are generally finer (coarse sands with crossbedding structures), intruded by horizons of small gravels and organic materials. The rivers closer to the Carpathian source-area (such as Suceava and Moldova) present much coarser Holocene sediments, with a sedimentary structure composed of superimposed gravel bars, lateral accretion lobes and up-fining sedimentation. At Siret river, which flows at a greater distance of the Carpathian source, the fine part of the Holocene deposits is the prevailing one and in the $7 \mathrm{~m}$ terrace a fossil soil profile was mapped, which is not very common in the floodplains of gravel-bed rivers.

The number of datings smaller than three per millennium did not allow us to better describe the individualization of more numerous phases of fluvial activity in the Early Holocene, up to 7000 YBP. Past climate reconstructions for the Romanian territory (A Persoiu, 2017) have shown that the Early and Mid-Holocene were dominated by warm and relatively dry intervals that extended until the 4700 YBP moment, when a sudden change occurred in the climatic regime. After the 4700 YBP moment, the cold and wet periods prevailed. Consequently, the flooding episodes had a greater intensity during the second half of the Holocene. This is confirmed in this case by the distribution on 100 years frequency classes of the age datings on fluvial units (Fig. 7D). The available age datings of the fluvial units deposited in special hydrodynamic conditions are grouped, during the last 6000 years, in a series of clusters. This finding leads us to the assumption that, the highest probability for flooding phenomena to occur was in the Mid to Late Holocene. Moreover, a second processing technique of the age datings (using Oxcal calibration curves, Reimer et al., 2013) produced the probability function density curves (Fig. 7E) which have the advantage that, by summing and normalization (cf Hoffman et al., 2008), can identify more detailed the high clustering phases of the exceptional hydrological events occurring on rivers at a centennial and multicentennial timescale. Episodes of flooding were identified where the relative probability exceeded the mean and where at least three dates occurred within two centuries in the corresponding part of the date frequency plot (cf Macklin et al., 2010). Therefore, the results presented in Fig. 7E are more relevant comparative to the frequency distributions from Fig. 7D. The peaks that surpass the mean value of the relative probability indicate that during that time the fluvial activity on the rivers had a greater intensity than in other time intervals. These years are indicated on the figure next to the peaks, respectively: $6200,5300,4100-4080,3600,2300-2200,1900$, $1300,950,750,520$ YBP.

The fluvial units on the rivers from Siret basin which were exemplified here, supplemented by other documented reports for Romania (Howard et al., 2004; Perșoiu, 2010; Bonsall et al., 2015; Perșoiu and Rădoane, 2017) lead to the conclusion that periods of alluvial sedimentation correlate well with episodes of climatic cooling, higher rainfall and enhanced river activity.

In order to argument this observation, we combined several records of the variability of paleoclimates on the territory of Romania, and we selected those that are continuous over the entire Holocene, or at least in the Mid- to Late Holocene. 


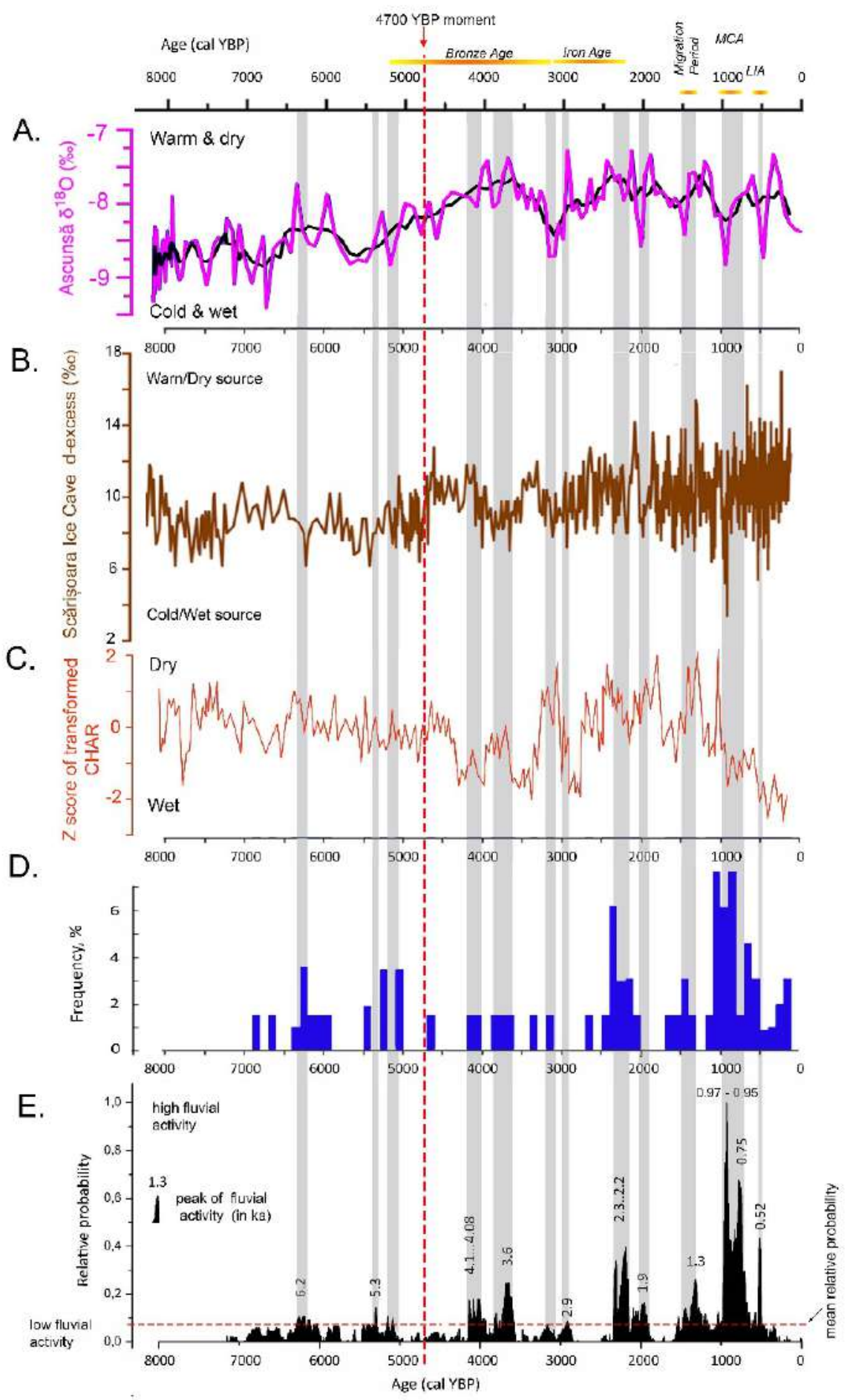

Figure 7 Fluvial activity for East Carpathian rivers and correlations with other paleoenvironmental indicators from Romanian territory in the last 8ka: A. Speleothem $\delta 180$ records from Ascunsă Cave, Mehedinți, SE Carpathians (Drăgușin et al., 2014); B. Scărișoara Ice Cave d-excess record (Perșoiu et al., 2017); C. Z-score of charcoal accumulation rate at Lake Știucii (Feurdean et al., 2013); D. The frequency of the calibrated ages for the fluvial units of the investigated rivers; $E$. The distribution of the summed relative probability of the calibrated ages for the fluvial sedimentary units. The years marked on the plot indicate peaks with intense fluvial activity on rivers. Discussions in the text 
The proxy data that we used for the paleoclimates analysis were gathered from: speleothem isotop record from Ascunsă Cave (Mehedinți Mts, Southern Carpathians) (Drăgușin et al., 2014); ice stable isotope record from Scărișoara Cave (Bihor Mts, Western Carpathins) (Perșoiu et al., 2017); sedimentary charcoal record from Lake Știucii (Transylvania Plain) (Feurdean et al., 2013). All the three categories of proxy data present a common variability trend, given by the change benchmark from around 4700 YBP (that we highlighted in Fig. 7 through a red line).

A common variability trend is observed at all the three categories of proxy data which show the same change threshold, situated around 4700 YBP (this was highlighted with a broken red line in Fig. 7). A similar tendency is also visible in the case of rivers activity (a greater number of sedimentation events during floods, respectively) in the second half of the Holocene (in terms of both frequency of events, Fig. 7D, and of the relative probability of events, Fig. 7E). The fluvial activity peaks were lengthened with a grey band so that the correspondence with the variability of the other climatic proxies could be followed. It is not our intention to get the perfect adjustment of the wetter and colder phases with the drier and warmer ones. This would be an exaggeration, given the climatic complexity over the territory of Romania and the inherent limitations within the climatic proxy data taken into account. However, we can keep in mind two general observations from the analysis of the diagrams, respectively: (i) different environmental processes speleothem growth rate, ice accumulation rate in the cave, charcoal accumulation rate providing information about the drivers of fire regimes, fluvial processes intensity) were predominantly controlled by the climatic variability from the Holocene; (ii) during the second part of the Holocene (especially post $4.7 \mathrm{ka}$ ) occurred more flooding episodes that coincided with the wet and cold periods identified as well in the variation of the other proxy data (for example, a lower charcoal accumulation rate in the sediments from Lacul Stiucii, lower values of the $\delta 180$ and d-excess both indicating a cold and humid source of precipitation, smaller values of the stable isotopes in speleothemes). The climatic explication of these modifications was discussed by Perșoiu (2017), Perșoiu et al., (2017) and consists in a shift from NAO- to NAO+ in the North Atlantic, the latter becoming dominant since $\sim 4.7 \mathrm{kcal} B P$ (with interruptions most notably, between 4.2 and $2.5 \mathrm{kcal}$ BP).

Returning to the study cases from this paper, we can use these palaeoclimatic information to explain a great part of the major moments of river channels dynamics change. For example, on Suceava river (Fig. 4), the discharges on the valley around 2200 YBP were so high that determined a wide avulsion process, causing the river to change its course direction on a distance of about $3 \mathrm{~km}$ and separating, in the middle of the floodplain, the 5-7 $\mathrm{m}$ terrace on which Prelipca village is settled today. The traces of the channel previous to 2200 YBP are preserved within the floodplain at the 3.5-4 m level. The new course of the Suceava river channel was kept until present with reduced migration within the fluvial corridor. The most significant gravel depositions with large lobes structure occurred in 950 and 780 YBP and the fine gravels with oblique structure were sedimented in 520 YBP. All these sedimentary units reflect an intense hydrodynamic activity, typical to extremely rainy periods in the river basin, which were documented by the above mentioned palaeoclimatic studies. The moments described above are concurring with the cold and wet climatic phases highlighted by the variation of all the proxy data represented in Fig. 7 and occurred at the end of the Iron Age. The following instability periods reported at Verești site were simultaneous with the so-called Medieval Climatic Anomaly and with LIA.

On Moldova river (Fig. 5), in the described sector, both the quarry pits openings and the resistivity profiles highlighted a wide sedimentation phase with a 3-4 m thick gravel sheet dated with $14 \mathrm{C}$ at 3700-3000 YBP, a palaeoclimatic interval favourable to exceptional flooding even in the west of Romania (Perșoiu, 2017). This interval occurs during Bronze Age and the climatic proxies indicate, more or less, a climatic period favourable to flooding (Fig. 7).

On Siret river, the wet phases of the Holocene manifested through floods that determined the 
accumulation of lateral accretion lobes (formed by small gravel that succeed from $5.2 \mathrm{ka}$ cal BP to 4.9 ka cal BP, typical to a sinuous to meandering channel as the one of Siret river). The 2200 YBP moment has also been marked in the sedimentary archive of Siret river at Liteni, by the incision of a channel in sediments older than Mid-Holocene which was subsequently filled with finer flood sediments (Fig. 6A). Using both the structure of the dated floodplain sediments and the identified paleo-terraces on floodplain surface we estimated a lateral channel migration rate of $700-1000 \mathrm{~m}$, while the alluvial material was re-worked, especially through lateral accretion processes (Rădoane et al., 2015). The lateral migration process was accompanied and boosted by avulsion phenomena (as we showed on Suceava river), the frequency of which is connected to the periods with exceptional pluvial and hydrological events.

The fluvial sedimentation activity, intensified by the exceptional hydrologic events, has been intercalating with the intervals when rivers deepened in their own sediments, this phenomenon leading to the formation of floodplain terraces. In the case of the rivers that we investigated, three or four generations of floodplain terraces were identified at the 5-7 m, 3-4 $\mathrm{m}$ and 2.5-3 $\mathrm{m}$, the active belt on which the present channel oscillates being situated below $2 \mathrm{~m}$ height. The exact dating of the incision phases is more difficult to obtain. The estimation of floodplain terraces detachment was made by correlating this process with the warmer and drier intervals of the Holocene which intercalated with the wet ones. The warmer intervals, with a stronger vegetation cover and only slight human activity were optimal for river channels incision. The deepening and sedimentation did not exclude each other along time. On the contrary, during the colder time intervals, along the sediment deposition processes there were also river channels incisions and great lateral mobility (avulsions), whereas in the warmer time intervals, except for a generalized incision, local sedimentation phenomena and reworking of the alluvial sediments were also possible. Our results as well as the ones documented by other studies (Macklin et al., 2006; Starkel et al., 2006; 2012; Perșoiu, 2010; Panin and Matlakhova, 2015; Perșoiu and Perșoiu, 2018), show that the process of river channels deepening was prevailing during the Early and Mid-Holocene and that the sedimentation, avulsion and incision processes had a much more pronounced activity rhythm in the second part of the Holocene (Rădoane et al., 2018).

The conclusion of these discussions draws the attention upon the interpretation potential given by the fluvial archives in deciphering the Holocene sedimentation history. In this case, we could identify a general pattern of this history for the East-Carpathian rivers, by putting together the sedimentation phases during the Mid- and Late Holocene, the avulsion and lateral migration processes that accompanied the high fluvial activity periods and the patterns of river channels morphological adjustment from braiding to wandering and to sinuous-meandering. The chronological overlay of the events indicates that during the Mid- and Late Holocene, the time intervals with the most ample fluvial processes on the rivers that drain the Eastern Carpathians were (in BP years): 6200, 5300, 4100-4080, 3600, 23002200 (Iron Age), 1300 (Migrations Period), 950-970 (Medieval Climate Anomaly), 750 and 520 BP (Little Ice Age) and that these intervals generally overlay the palaeoclimatic episodes characterized by high amounts of precipitation. Coming to more recent years, for example, the last 200 years, the investigations regarding river channels dynamics (especially plane configuration change) have indicated for the first time an unprecedented increase of the anthropic component weight amongst the causes of the phenomenon. Consequently, the human impact is now competing with climate changes for the greatest share in controlling fluvial processes (Perșoiu and Rădoane, 2011; Rădoane et al., 2013, 2017).

\section{References}

Benito G, Macklin MG, Panin A, Rossato S, Fontana A, Jones AF, Machado MJ, Matlakhova E, Mozzi P, Zielhofer C. 2015. Recurring flood distribution patterns related to short-term Holocene climatic variability. Scientific Reports, 5. DOI:10.1038/srep16398

Bonsall C, Macklin MG, Boroneant A, Pickard C, Bartosiewicz L, Cook GT, Higham TFG. 2015. Holocene climate change and prehistoric settlement in the 
lower Danube valley. Quaternary International, 378: 14-21. DOI:10.1016/j.quaint.2014.09.031

Bridge JS, Leeder MR.1979. A simulation model of alluvial stratigraphy. Sedimentology, 26: 617-644

Chiriloaei F. 2012. Analiza cantitativă a modificărilor albiei râului Moldova în sectorul extracarpatic. PhD. Thesis. Alexandru Ioan Cuza. (in Romanian)

Chiriloaei F, Rădoane M, Perşoiu I, Popa I. 2012. Late Holocene history of the Moldova River Valley, Romania. Catena, 93, 64-77. DOI:10.1016/j.catena.2012.01.008

Cordier S, Briant B, Bridgland D, Herget J, Maddy D, Mather A, Vandenbergh J. 2017. The Fluvial Archives Group: 20 years of research connecting fluvial geomorphology and palaeoenvironments. Quaternary Science Reviews, 166: 1-9.

Donisă I. 1968. Geomorfologia Văii Bistriței. Romanian Academy Press, București. (in Romanian)

Drăgușin V, Staubwasser M, Hoffmann DL, Ersek V, Onac BP, and Vereș D, 2014. Constraining Holocene hydrological changes in the Carpathian-Balkan region using speleothem 180 and pollen-based temperature reconstructions. Clim. Past, 10: 1363-1380.

Faust D, Wolf D. 2017. Interpreting drivers of change in fluvial archives of the Western Mediterranean - A critical view. Earth-Science Reviews, 174: 53-83. DOI:10.1016/j.earscirev.2017.09.011

Feurdean A, Liakka J, Vanniere B, Marinova E, Hutchinson SM, Mosburgger V, Hickler T. 2013. 12,000 Years of fire regime drivers in the lowlands of Transylvania (Central-Eastern Europe): a data-model approach. Quaternary Science Reviews, 81: 48-61. doi.org/10.1016/j.quascirev.2013.09.014

Hoffmann T, Lang A, Dikau R. 2008. Holocene river activity: analysing14C-dated fluvial and colluvial sediments from Germany. Quaternary Science Reviews, 27: 2031-2040. DOI:10.1016/j.quascirev.2008.06.014

Ichim I, Rădoane M. 1990. Channel sediment variability along a river: A case study of the Siret River, Romania. Earth Surface Processes and Landforms, 15: 211-225.

Howard AJ, Macklin MG, Bailey DW, Mills S, Andreescu R. 2004. Late-Glacial and Holocene river development in the Teleorman Valley on the southern Romanian Plain. Journal of Quaternary Science, 19: 271-280. DOI:10.1002/jqs.805

Johnstone E, Macklin MG, Lewin J. 2006. The development and application of a database of radiocarbon-dated Holocene fluvial deposits in Great Britain. Catena, 66: 14-23. DOI:10.1016/j.catena.2005.07.006

Lewin J, Macklin MG 2003. Preservation potential for late quaternary river alluvium. Journal of Quaternary Science, 18: 107-120. DOI:10.1002/jqs.738

Lewin J, Macklin MG, Johnstone E. 2005. Interpreting alluvial archives: Sedimentological factors in the Brit- ish Holocene fluvial record. Quaternary Science Reviews, 24(16-17): 1873-1889

DOI:10.1016/j.quascirev.2005.01.009

Macklin MG, Lewin J. 2003. River sediments, great floods and centennial-scale Holocene climate change. Journal of Quaternary Science, 18: 101-105. DOI:10.1002/jqs.751

Macklin MG, Benito G, Gregory KJ, Johnstone E, Lewin J, Michczyńska DJ, Soja R, Starkel L, Thorndycraft VR. 2006. Past hydrological events reflected in the Holocene fluvial record of Europe. Catena 66: 145-154. DOI:10.1016/j.catena.2005.07.015

Macklin MG, Jones AF, Lewin J. 2010. River response to rapid Holocene environmental change: evidence and explanation in British catchments. Quaternary Science Reviews, 29: 1555-1576. DOI:10.1016/j.quascirev.2009.06.010

Miall AD. 1985. Architectural-Element Analysis: A New Method of Facies Analysis Applied to Fluvial Deposits. Earth-Science Reviews, Elsevier Science Publishers B.V 22: 261-308. DOI:10.1016/0012-8252(85)90001-7

Mîndrescu M, Florescu G, Grădinariu I, Haliuc A. 2017. Lakes, lacustrine sediments and paleoenvironmental reconstructions. In: Rădoane $M$, Vespremeanu-Stroe A. (eds.): Landform Dynamics and Evolution. Springer, pp. 699-736.

Necea D, Fielitz W, Kadereit A, Andriessen PAM, Dinu C. 2013. Middle Pleistocene to Holocene fluvial terrace development and uplift-driven valley incision in the SE Carpathians, Romania. Tectonophysics, 602: 332354. DOI:10.1016/j.tecto.2013.02.039

Niculiță M, Mărgărint MC, Santangelo M. 2016. Archaeological evidence for Holocene landslide activity in the Eastern Carpathian lowland. Quaternary International, 415: 175-189.

Oprea D. 2014. Valea Sucevei. Studiu geomorfologic. PhD Thesis. "Ștefan cel Mare" University of Suceava.

Panin A, Matlakhova E. 2015. Fluvial chronology in the East European Plain over the last $20 \mathrm{ka}$ and its palaeohydrological implications. Catena, 130: 46-61. DOI:10.1016/j.catena.2014.08.016

Perșoiu A. 2017. Climate evolution during the Late Glacial and the Holocene. In: Rădoane $\mathrm{M}$, VespremeanuStroe A. (eds.): Landform Dynamics and Evolution. Springer, pp. 57-66.

Perşoiu A, Onac BP, Wynn JG, Blaauw M, Ioniță M, Hansson M. 2017. Holocene winter climate variability in Central and Eastern Europe. Scientific Reports, 7: 1-8. DOI:10.1038/s41598-017-01397-w

Perșoiu I. 2010. Reconstituirea evoluției geomorfologice a văii Someșul Mic în Holocen. Ph.D. Thesis. "Alexandru Ioan Cuza" University of Iași. (in Romanian) 
Perşoiu I, Rădoane M. 2011. Spatial and temporal controls on historical channel responses - Study of an atypical case: Someşu Mic River. Romania. Earth Surface Processes and Landforms, 36: 1391-1409. DOI:10.1002/esp.2169

Perșoiu I, Rădoane M. 2017. Fluvial Activity During the Holocene. In: Rădoane $M$, Vespremeanu-Stroe $A$. (eds.): Landform Dynamics and Evolution. Springer Verlag, pp. 469-488.

Perșoiu, I, Perșoiu, A. 2018. Flood events in Transylvania during the Medieval Warm Period and the Little Ice Age. The Holocene, DOI:10.1177/0959683618804632

Perșoiu I, Rădoane M, Urdea P. 2017. River behavior during Pleniglacial - Late Glacial. In: Rădoane M, Vespremeanu-Stroe A. (eds.): Landform Dynamics and Evolution. Springer, pp. 443-468.

Rădoane M, Radoane N, Dumitriu D. 2003. Geomorphological evolution of longitudinal river profiles in the Carpathians. Geomorphology, 50: 293-306. DOI:10.1016/S0169-555X(02)00194-0

Rădoane M, Rădoane N, Dumitriu D, Miclăuş C. 2008. Downstream variation in bed sediment size along the East Carpathian rivers: Evidence of the role of sediment sources. Earth Surface Processes and Landforms, 33: 674-694. DOI:10.1002/esp.1568

Rădoane M, Obreja F, Cristea I, Mihailǎ D. 2013. Changes in the channel-bed level of the eastern Carpathian rivers: Climatic vs. human control over the last 50 years. Geomorphology, 193: 91-111. DOI:10.1016/j.geomorph.2013.04.008

Rădoane M, Nechita C, Chiriloaei F, Rădoane N, Popa I, Roibu C, Robu D. 2015. Late Holocene fluvial activity and correlations with dendrochronology of subfossil trunks: Case studies of northeastern Romania. Geomorphology, 239: 142-159. DOI:10. 1016/ j.geomorph. 2015.02 .036

Rădoane M, Perșoiu I, Chiriloaei F, Cristea I, Robu D. 2017. Styles of Channel Adjustments in the Last 150 Years. In: Rădoane $M$, Vespremeanu-Stroe A. (eds.): Landform Dynamics and Evolution in Romania, pp. 489518. DOI:10.1007/978-3-319-32589-7
Rădoane M, Chiriloaei F, Sava T, Nechita C, Rădoane N, Gâza O. 2018. Holocene fluvial history of Romanian Carpathian rivers. Quaternary International, DOI: 10.1016/j.quaint.2018.11.014

Reimer PJ, Bard E, Bayliss A, Beck JW, Blackwell PG, Ramsey $C B$, Buck $C E$, Cheng $H$, Edwards $R L$, Friedrich $M$, Grootes PM, Guilderson TP, Haflidason H, Hajdas I, Hatté $C$, Heaton TJ, Hoffmann DL, Hogg AG, Hughen KA, Kaiser KF, Kromer B, Manning SW, Niu M, Reimer RW, Richards DA, Scott EM, Southon JR, Staff RA, Turney CSM, Plicht J van der. 2013. IntCal13 and Marine13 Radiocarbon Age Calibration Curves 0-50,000 Years cal BP. Radiocarbon, 55: 1869-1887. DOI:10.2458/azu_js_rc.55.16947

Rossato S, Fontana A, Mozzi P. 2015. Meta-analysis of a Holocene $14 \mathrm{C}$ database for the detection of paleohydrological crisis in the Venetian - Friulian Plain (NE Italy). Catena, 130: 34-45. DOI:10.1016/ j.catena. 2014.10.033

Starkel L, Soja R, Michczynska DJ. 2006. Past hydrological events reflected in Holocene history of Polish Rivers. Catena, 66(1-2): 24-33.

Starkel L, Michczyńska DJ, Krąpiec M, Margielewski W, Nalepka D, Pazdur A. 2012. Progress in the Holocene chrono-climatostratigraphy of Polish territory. Geochronometria, 40: 1-21. DOI:10.2478/s13386-0120024-2

Starkel L, Michczyńska DJ, Gebica P, Kiss T, Panin A, Perşoiu I. 2015. Climatic fluctuations reflected in the evolution of fluvial systems of Central-Eastern Europe (60-8 ka cal BP). Quaternary International, 388: 97118. DOI:10.1016/j.quaint.2015.04.017

Vespremeanu-Stroe A, Zăinescu F, Preoteasa L, Tătui F, Rotaru S, Morhange C, Stoica M, Hanganu J, TimaGabor A, Cârdan I, Piotrowska N. 2017. Holocene evolution of the Danube delta: An integral reconstruction and a revised chronology. Marine Geology, 338: $38-61$.

*Fluvial Archives Group, 1996.

https://www.geo.vu.nl/ balr/FLAG/web_data 